\title{
Successful Online Teaching Using An Asynchronous Learner Discussion Forum
}

\author{
Mark H. Rossman, Ed.D \\ Capella University \\ $3302^{\text {nd }}$ Avenue South, Suite 550 \\ Minneapolis, Minnesota \\ Phone: 800-987-2282 ext 217 \\ E-mail: mrossman@ capella.edu
}

\begin{abstract}
At Capella University online courses are offered using an asynchronous learner discussion forum. At the conclusion of each course, learners are requested to complete and electronically submit a course evaluation form.

A document analysis of more than 3000 course evaluations from 154 courses conducted during the past 11 quarters was conducted. Each course folder was reviewed. The narrative responses were ultimately grouped into the following categories: Faculty Feedback, Learner Discussions and Course Requirements. General observations related to these categories were presented followed by several tips for successful teaching in an online environment using an asynchronous learner discussion forum. The tips were initially generated by the document analysis. Additional tips were added and the list was revised each quarter following the end-of-quarter teleconference with the instructors.
\end{abstract}

\section{KEYWORDS}

ALN, Teaching and learning at a distance, Facilitating asynchronous discussions, Online teaching

\section{INTRODUCTION}

Capella University was founded in 1992, and accredited in 1997 by the North Central Association of Colleges and Schools Commission on Institutions of Higher Education (NCA) to offer degrees in Education, Human Services, Psychology and Organization and Management. It is a higher education institution that offers undergraduate and graduate degree programs, certificates and continuing education to adult learners who seek to integrate advanced study with their professional lives. Its mission is to deliver high-quality programs that provide traditional and contemporary knowledge through flexible and innovative forms of distance learning. Its delivery system consists of online courses incorporating an asynchronous discussion forum and directed study courses utilizing learning contracts between a course tutor and the learner.

Capella University explicitly recognizes adult learners as active partners in the design and implementation of their academic experience and embraces a learner-focused educational philosophy. Recognizing that adult learners possess a wealth of knowledge, experience and maturity, the programs at Capella University honor and build upon these attributes. From the recognition that education and learning must be a continuous, lifelong process in our constantly changing world, special emphasis is placed on helping learners develop self-managed learning skills and personal leadership attributes. 
Central to the teaching and learning experience at Capella University are collaborative learning relationships with faculty and a focus on integrating high quality academic and scholarly work with professional relevance and application. Distance learners familiar with the advantages presented by technology are common in distance education courses and programs. Indeed, "today's adult learners ... frequently arrive at our doorsteps realizing that the technologies of fax machines, e-mail, internet, and other forms of computer-mediated technologies are readily available" [1]. Teaching and learning in distance learning settings is a topic that is receiving much attention in today's educational melieu. Much has been written regarding teaching and learning and the Internet [2], [3], [4], [5], [6], [7], [8]. Many adult educators advocate that success in Internet courses can be accomplished by developing activities based on adult learning principles. One key to success is to listen to the learners.

\section{COURSE FORMAT}

At Capella University, all online courses use a similar format. Courses are divided into units (usually 8) and each unit presents information in the form of small lectures, assigned readings, library assignments or a combination thereof. Using an asynchronous learner discussion forum, questions are presented by the course tutor. Learners are required to post responses not only to the questions posed by the tutor but also to responses of other learners, thereby applying the concept that adult learners have experiences and insights that are valuable and should be included within any class discussion.

Diagrammatically, a typical threaded discussion among five learners and the course tutor may be depicted as follows:

Unit discussion question \#1 (presented by the course tutor)

Response by learner \#1 to unit discussion question

Response by learner \#2 to unit discussion question

Response by learner \#3 to learner \#2

Response by learner \#4 to learner \#3's response to learner \#2

Response by learner \#3 to unit discussion question

Response by learner \#2 to learner \#3

Response by course tutor to learner \#3

Response by learner \#5 to unit discussion question

Response by learner \#2 to learner \#5

Response by learner \#4 to learner \#5

Summary statement by course tutor relating to Discussion Question \#1.

\section{COURSE EVALUATION}

At the conclusion of each course, learners are requested to complete and electronically submit a course evaluation form. The form calls for the learner to rate the course on several dimensions using one of five descriptors and to provide narrative responses regarding the following: aspects of the course that were enjoyed most and least, the content that could be changed to strengthen the course, suggestions to the course facilitator to better assist future learners, observations about the distance learning experience and any other comments or feedback of a general nature. 
The name, address and any other identifying characteristic of the sender are removed. The "edited" evaluation is transferred to a course folder and the director of faculty development comments on perceived strengths and weaknesses. When the quarter is concluded, the course folders are sent to the faculty and Deans of the schools, and quarterly follow-up teleconferences are conducted using observations gleaned from learner comments.

Beginning with the Fall quarter 1999 a more sophisticated tracking system will be implemented allowing for more detailed analysis. For example, reports can be generated listing all responses to each question for the course. Profiles from the various schools within Capella generated by the rating system will be able to be developed. Patterns over time will emerge as will patterns related to the age, experiential or educational backgrounds of the participants.

Beginning with the Fall quarter, 1996 and continuing through the Summer quarter, 1999, more than 3000 learner evaluations that have been sent electronically by learners in 154 courses. Approximately $60 \%$ of the learners have completed the course evaluation.

\section{DATA ANALYSIS}

Recently, a document analysis of the 3000+ evaluations submitted over a period of 11 quarters was conducted. Using a modification of the "index card" system of data analysis suggested by Guba and Lincoln [9], information from each course folder was reviewed and abstracted onto index cards, the first card beginning the first pile; "the second card is then assessed to determine whether it is similar or different from the first. If it is similar, it is placed into the same pile, but if it is different, a new pile is formed" [9 (p. 314)]. Three piles emerged, were judged to be comprehensive and illuminating, and were named Faculty Responsibility, Facilitating Discussions, and Course Requirements. Within each category, several subtopics were identified.

\section{A. Faculty Responsibility}

1) Learners want prompt feedback from faculty and seem to appreciate it when these comments were posted in the discussion forum in a timely manner.

2) Learners want specific feedback and view comments such as "nice job" or "good response" as being indicative of a disinterested or lazy faculty member.

3) Learners do not object to opinions being challenged as long as the individual was not belittled or humiliated for offering the response.

4) Learners prefer that negative comments be given privately, preferably through a phone call.

\section{B. Facilitating Discussions}

1) Learners appreciate and seemed to learn much from the responses of other learners.

2) Learner responses seem to be a valuable aspect of the course.

3) There is perceived guilt among some learners about not posting when postings of other learners have captured the essence of what they wanted to say.

4) Learners do not like it when fellow classmates did not keep current with the weekly online posting requirements.

5) Learners prefer discussion forums that encourage open and honest dialog; are not dominated by one or two "dominant voices;" and are not used to express non-course-related concerns or complaints. 


\section{Course Requirements}

1) Learners want guidelines from faculty regarding course requirements.

2) Learners were dissatisfied when URLs were inoperative or incorrect.

3) Learners want to immediately apply information gleaned in class to life or work situations.

4) Learners did not like being required to purchase books, articles, various programs or other required material that were not fully utilized by the course instructor.

\section{TIPS FOR SUCCESSFUL ONLINE TEACHING}

At the end of each quarter a teleconference is conducted when faculty can share observations related to successes and problems. Topics derived from learner evaluations of the just concluded quarter are also discussed. Faculty are encouraged to offer suggestions and comments designed to improve the instructional process. Several tips, some similar to those developed by Berge [10], Burge and Roberts [11] and Eastmond [12] have been developed and are presented using the categorization system described above.

\section{A. Faculty Responsibility}

Feedback! Feedback! Feedback! Online learners need it and can not seem to get enough. Feedback (or the lack thereof) is the most frequently mentioned concern of online learners. To quote from learner online evaluations, faculty who provide meaningful and frequent feedback are viewed as "excellent," "very good," "concerned" and "caring" while those who provide it superficially or infrequently are viewed as "not very good," "poor," "unconcerned" and "arrogant."

Develop a group e-mail list for the class and send weekly notes on class business. Encourage learners to send private e-mail messages or to phone the instructor as appropriate. One needs to be cautious of this because MOST class business should be shared rather than to create behind the scenes discussions.

Send personal notes throughout the online course to simulate the informal chat that often occurs at the beginning of a traditional class.

In classes where learner responses are required, faculty need to keep track of those who respond and those who do not. One way to do this is to ask learners to label their responses sequentially. Doing this helps the faculty member to keep track of how learners are progressing. This can be accomplished by preparing a spreadsheet before class. In the first column list each learner's name. Across the top list everything learners need to do in each unit. Table 1 shows a sample matrix.

\begin{tabular}{|l|l|l|l|l|}
\hline Name & $\begin{array}{l}\text { U1 } \\
\text { paper }\end{array}$ & U1 - Pt1 & U1 - Pt2 & U1 -Pt3 \\
\hline Smith & Y & Y & Y & Y \\
\hline Jones & & Y & Y & Y \\
\hline
\end{tabular}

Table 1. Sample Tracking Matrix Used by Faculty.

This means that in the first Unit (U1) there is a paper, as well as three parts to the discussion. The course facilitator reviews the Discussion Group or reads the required paper and puts a "Y" in the appropriate cell of the spreadsheet to indicate that a learner had completed a specific item. The benefit of doing this, other than recording what has happened, is that at a glance the faculty 
member can see who is falling behind. A gentle reminder (an e-nudge) can be sent to these learners noting that they are behind and asking if there is a problem or what can be done to help. For group projects, the course facilitator can check off a learner if he or she has participated in the group activity. In the example above, Jones has completed the discussion, but not the assignment. Smith is up to date.

Encourage learners to complete course evaluations. This provides meaningful evaluation not only for faculty improvement but it also is an important way of providing learners with a forum to express concerns, raise course-related issues and to provide other feedback.

Encourage learners to engage each other in debate when the spirit moves them--this adds an element of dynamism that provokes lots of interest in the content.

If articles or materials are found that might be helpful to the other learners now or in the future, post citations or URLs as well. Do not post the entire article unless copyright clearance is obtained. Keep a record of these postings, as this will help the faculty member to compile a list of new resources for future course revisions.

In many classes, size precludes the course instructor from responding individually to each learner response. In face-to-face (FTF) learning environments, the instructor responds to most comments verbally or non-verbally. In the electronic environment, this is not possible but prior conditioning coupled with the physical separation of learners and faculty seems to create an expectation that the facilitator respond to every written comment. A reasonable solution is to emphasize learner comments in a summary statement. For example, if several learners have made similar or related comments around a common theme, the summary statement might be something like this: "Sam, Jenny and $\mathrm{Al}$ have made an interesting point. It seems as though. .."

Encourage learners to be on the lookout for URLs that interface with the course content units and to post them to the discussion forum for all to see. Keep track of these to enhance the next offering of the course.

\section{B. Facilitating Discussion}

Present a personal introduction the first week. This provides a model for learner introductions and encourages learners to view faculty members a real people with concerns and problems just like the learners. Don't hesitate to reveal details about family, children, or one's "non-teaching" life. This helps the learner to realize that the course instructor and the learners have much in common. Both are adults and subject to similar stresses and strains.

Send a picture of yourself to all learners at all sites. This can be done electronically or via the mail. Several learners and faculty have reported that this helps take some of the distance out of distance learning. Faculty may want to add some audio and video as well.

Encourage learners to pass on to one another any helpful hints they may have or hear about regarding success at the home institution.

Let learners know if you are comfortable with a first name basis for those who wish to address you by your first name. Also, don't assume that learners are comfortable with being called by their first name either. Raise these concerns early in the course as well. 
Communication using asynchronous postings to the discussion forum allows learners to post at their convenience. This also allows learners to complete assigned readings, reflect on the contributions of others, and construct a thoughtful, well-prepared contribution before posting to the discussion forum. As a result, the quality of discussion usually reflects a higher level of scholarly discourse than is typical in many FTF classes.

Post a weekly summary of the class discussion for the prior week. Some faculty wait until the end of a unit before posting their "official" response. By waiting until the end of the week to provide a full summary statement, the discussion has run its course and participants have expressed their views independent of those of the course facilitator. The summary provides closure.

It is very helpful for the faculty member to develop a response to a discussion topic before it is presented to the class. When it comes time to post, modify it in light of the discussion. This is a real time saver.

Make every effort to keep learners up to speed with the discussion's progress. It is a rich source of learning, enjoyment, and an integral part of the course. Learners who do not regularly post or post late are a frequent source of contention to other learners as it is felt that these learners are slacking off or are not pulling their weight. It is the facilitator's responsibility to monitor the quality and regularity of learner postings. If a learner is experiencing difficulty in this regard, the instructor should discuss this in private and not on the discussion board.

Keep all comments positive in the forum-discuss negative feedback privately. Remember that online communication is limited to the written word, which lacks the subtleties and nuances of FTF communication. In addition, the communication is preserved in the discussion forum and is available for everyone to see. Initiating a debate in the discussion group is encouraged as long as it has a positive tone.

Learners frequently have expertise related to the subject matter of the course and should be encouraged to share their knowledge with their classmates. One way of doing so is to invite selected learners to facilitate a discussion on a special topic related to an assigned reading.

Online courses are not conducive to lecturing, so instructors who facilitate learners' mastery of course objectives by encouraging discussion of topics related to assigned reading are typically more effective than those who post lengthy presentations. The key here is to keep the discussion moving and focused on the assigned topic.

Keep notes about each learner so that you are reminded about learner interests and experience. This helps the facilitator to more appropriately shape responses.

\section{Course Requirements}

Be sure to let the class know what your expectations are for the course. This should be done as early as possible in the course. For example, how quickly will you generally respond to a learner comment? What are your expectations regarding writing clarity and organization? Be as specific as possible about what your requirements for projects and/or papers. Do you want papers to follow a specific form and style guide? Also be explicit as to whether the paper should be emailed or posted in the discussion forum. 
Be sure to negotiate the final project requirements, if required, with the learner well in advance of the time it is due. Learners want and need feedback about what is expected and the criteria for acceptance.

The most difficult part of a course for many faculty is finding the dedicated time at the end to go through all the final papers or projects. Planning this time in advance helps.

\section{SUMMARY}

The skills involved in online teaching settings using an asynchronous learner discussion forum do not simply happen. Online teachers are aware that there is quite a difference when teaching in a FTF classroom and teaching online. Teaching online demands that the "Sage on the Stage" give way to the "Guide on the Side." Facilitating learning is becoming much more of a focus than ever before. Research generated by Capella University has developed suggestions relating to faculty responsibility, facilitating learner participation in the discussion forum and course requirements. It has also developed the above suggestions for improving online teaching.

\section{REFERENCES}

1. Kent, E. and Shaughnessy, M.E., Peering into Cyberspace: An Examination of the Issues Facing Faculty and Adult Learners Entering the Realm of Distance Learning, Proceedings for the Sixteenth Annual Alliance/ACE Conference. St. Pete Beach, FL, October 3-5, 1996.

2. Berge, Z. and Collins, M.P. (Eds.), Computer-mediated Communications and the Online Classroom, Vol. III, Distance Learning, Cresskill, N.J., Hampton Press, 1995.

3. Cahoon, B., New Directions for Adult and Continuing Education, Summer, No. 78, Adult Learning and the Internet, San Francisco, Jossey-Bass, 1998.

4. Collis, B., Tele-Learning in a Digital World: The Future of Distance Learning, New York, International Thomson Computer Press, 1996.

5. Cyrs, T. E. (Ed.), New Directions in Teaching \& Learning, Fall, No. 71, Teaching \& Learning at a Distance: What It Takes to Effectively Design, Deliver, \& Evaluate Programs. San Francisco, JosseyBass, 1977.

6. Eastman, D.V., Alone but Together: Adult Distance Study by Computer Conferencing, Cresskill, N.J., Hampton Press, 1995.

7. Porter, L. R., Creating the Virtual Classroom: Distance Learning with the Internet, New York, Wiley Computer Publishing, John Wiley \& Sons, Inc., 1977.

8. Rossman, M.H. and Rossman, M.E. (Eds.), New Directions for Adult and Continuing Education, Fall, No. 67, Facilitating Distance Education. San Francisco, Jossey-Bass, 1995.

9. Guba, E.G. and Lincoln, Y.S., Effective Evaluation, San Francisco, Jossey-Bass, 1981.

10. Berge, Z., Facilitating Computer Conferencing: Recommendations From the Field, Educational Technology, 35(1) 22-30, 1995.

11. Burge, E. and Roberts, J. M., Classrooms with a Difference: A Practical Guide to the Use of Conferencing Technologies, Toronto: Ontario Institute for Studies in Education, 1993.

12. Eastmond, D. V., Effective Facilitation Of Computer Conferencing, Continuing Higher Education Review, 56(1/2) pp. 23-34. 1992. 